\title{
TARGETING THE REDISTRIBUTIVE PAYMENT IN SELECTED NEW EUROPEAN UNION MEMBER STATES
}

\author{
Adrian SADŁOWSKI (D)* \\ Institute of Economics and Finance, Faculty of Social and Economic Sciences, \\ Cardinal Stefan Wyszyński University in Warsaw, Warsaw, Poland
}

Received 09 February 2021; accepted 14 September 2021

\begin{abstract}
The most important element in the recent reform of the Common Agricultural Policy, which is intended to reduce the concentration of aid distributed under the direct support system, is the so-called redistributive payment. The redistributive effects of this instrument depend on its specific form implemented at the national level, the level of funding, and the area structure of holdings in a given country. The objective of this paper is to compare the targeting of the support distributed under the redistributive payment in the three new Member States of the European Union - Bulgaria, Lithuania and Poland. In order to achieve this objective, it was established which area groups of holdings benefit from (and which lose out on) the application of the redistributive payment in each country. In addition, the average amount of support for a holding per hectare of agricultural area, and the percentage change in this support due to the introduction of the redistributive payment, depending on the size of the holding, in individual countries, are shown as a function. The source material was the data made available by the ministries of agriculture of the countries under analysis, relating to 2018 .
\end{abstract}

Keywords: Common Agricultural Policy, direct payments, direct support system, redistributive payment, single area payment, concentration of direct support, level of direct payments.

JEL Classification: Q10, Q12, Q18.

\section{Introduction}

Already before the last reform of the Common Agricultural Policy, which became effective in 2015 , it was pointed out that a large part of direct payments went to a relatively small group of very large holdings, and that this situation was stable over time (Sinabell et al., 2009). Severini and Tantari (2015) also stated that the degree of concentration of direct payments was heterogeneous in the Member States of the European Union, and reached very high values in some of them, and that the greater part of the variability in the degree of concentration of support could be explained by differences in the level of land concentration.

\footnotetext{
${ }^{\star}$ Corresponding author. E-mail: a.sadlowski@uksw.edu.pl
} 
In 2014, the concentration of payments was stronger in six Member States than in the European Union as a whole. These comprised as many as five new Member States (Slovakia, the Czech Republic, Bulgaria, Hungary, and Estonia) and only one EU-15 country (Portugal). The most uneven distribution of support was in Slovakia (Sadłowski, 2017).

The preamble to Regulation (EU) No. 1307/2013 of the European Parliament and Council of European Union (2013), implementing the reform of the Common Agricultural Policy which entered into force in 2015, states that the distribution of funds among farmers is characterised by the allocation of disproportionate amounts of payments to a relatively small number of large beneficiaries. At the same time, the need to distribute payments between small and large beneficiaries in a more balanced way, and to increase the effectiveness of income support for farmers with small holdings, was emphasised. The view was expressed that larger beneficiaries, due to their ability to exploit economies of scale, had the ability to operate with lower levels of aid, so they did not require so much support. One of the solutions which were intended to reduce the uneven distribution of aid between beneficiaries of the direct support system is the so-called redistributive payment.

Baisakova and Herzfeld (2014) mention the redistribution of funds in favour of smaller holdings among the most important elements in the recent reform of the Common Agricultural Policy in the first pillar. A fairer distribution of funds among farmers was to be ensured in particular by the redistributive payment (Beluhova-Uzunova et al., 2019). According to Beluhova-Uzunova et al. (2017), this instrument can help to overcome structural imbalances by channelling financial support towards agricultural sectors generating high added value. On the other hand, according to Sahrbacher (2011), solutions such as the upper payment limit, which is the second - in addition to the redistributive payment - instrument for reducing the imbalance in the distribution of funds, significantly slow down positive structural changes in agriculture. Deppermann et al. (2016) stress that there are still significant reserves in the area of redesigning Common Agricultural Policy instruments in such a way as to ensure a more even distribution of income in the agricultural sector. According to Grochowska et al. (2021) the criteria for granting direct payments still increase the income inequality of farms and the concentration of payments in a small group of farms, and instruments such as capping in the current shape are not sufficient to change this situation.

Currently, the redistributive payment is an optional instrument for Member States of the European Union, i.e. it is decided at the national level. However, a Member State does not receive additional funds from the European Union due to the introduction of voluntary payments. The decision of a Member State to apply the redistributive payment, therefore, does not affect the amount of EU funds put at its disposal for direct support (i.e. the so-called national ceiling), but only the way these funds are allocated at the national level (Sadłowski, 2018).

Among the new Member States, Bulgaria, Croatia, Lithuania, Poland, and Romania apply the redistributive payment (European Commission, 2016). All these countries, with the exception of Croatia, apply a simplified direct payment scheme (European Commission, 2018).

The objective of this paper is to compare the targeting of the support distributed under the redistributive payment in three new Member States of the European Union (Bulgaria, Lithuania, and Poland). 
The compared countries differ significantly in terms of the production potential of their agriculture. For instance, Eurostat (2021) data for 2016 show that the agricultural land area in Poland (approx. 14.4 million ha) was more than 3 times higher than that of Bulgaria (approx. 4.5 million ha), and almost 5 times higher than in Lithuania (approx. 2.9 million ha). Considering the issue of redistributive payment applications, it is of particular importance that in all these countries the land concentration process is progressing, albeit at varying rates. Eurostat data demonstrate that the number of agricultural holdings in 2016 declined as compared to 2013 by as many as $20.3 \%$ in Bulgaria, and $12.5 \%$ in Lithuania, while in Poland a $1.3 \%$ fall was recorded. This means that the drop rate in the number of agricultural holdings was the highest in the country in which the average holding size was the highest (Bulgaria), and the lowest in the country with the greatest fragmentation of holdings (Poland).

For the purpose of achieving the objective identified above:

1) area groups of holdings benefiting from/losing out on the application of the redistributive payment in each country were identified;

2) the average level of support (under the single area payment and the redistributive payment) per hectare of agricultural area in a holding, depending on its size, was established in each country (in absolute terms);

3) the percentage change in the average level of support per hectare of agricultural area in a holding due to the introduction of the redistributive payment, depending on the size of the holding, (in relative terms) was established.

The paper's structure corresponds to the research objective specified above. The introductory part is followed by the review of research in areas of key importance from the perspective of the subject matter of the paper, i.e. research relating to the issue of the uneven distribution of direct payments between the beneficiaries of the same support, and research aimed at identifying and measuring the effects of applying redistributive payments. After that, sources used in the author's research are presented, along with their origins, and also the methodology of the research. The presentation of the author's research results and their discussion constitute the next part of the study. The last section of the manuscript contains final conclusions formulated on a comparative basis, and the cognitive limitations of the author's research constituting the motivation for writing this paper, and possible directions for further research in this area are suggested.

The comparison analysis between countries presented in this paper is an innovation bridging the research gap in this field. In addition to the results showing essential cognitive and application benefits, the added value of this study is its self-developed analytical concept. It is presented in the form of an algorithm, at a level of detail enabling its critical assessment, the reconstruction of successive steps in order to verify the accuracy of the calculations, and the application of the proposed approach in studies with different spatial scopes (in other countries), or another temporal scope (other periods), contributing to accumulating knowledge in the field, which is especially important for supporting the process of designing the agricultural policy at the EU level, and for constructing - within the EU legal framework the national variant of the direct support system. 


\section{Overview of earlier research}

There are quite numerous publications presenting the results of research in the field of direct support concentration, and on the uneven distribution of direct payments between beneficiaries, relating to the situation in the period preceding the previous reform of the Common Agricultural Policy. They concern both old (von Witzke \& Noleppa, 2007; Keeney, 2008; Alfaro-Navarro et al., 2011; Severini \& Tantari, 2013a, 2013b; Ciliberti \& Frascarelli, 2015), and new, Member States of the European Union (Graca-Gelert, 2014; Šlajs \& Doucha, 2014; Jankowska, 2015). Some authors, as well as measuring the degree of the concentration of support, expressed their demands or evaluation judgements. In general, it was recommended to reform the direct payment scheme in order to reduce the concentration of aid. If there were a justification other than "the need for the fairer distribution of support", it was based on well-known arguments put forward by critics of large-scale agriculture, or by apologists of moderate agriculture.

Wilkin (2009) stresses that the question of income distribution and the impact of farming on social stratification are fundamental issues of political economics, and that the distribution of benefits from the Common Agricultural Policy, which is quite commonly regarded as a controversial element in the implementation of this policy, is directly linked to its social and political legitimacy. According to this author, the more egalitarian distribution of direct payments is one of the main tasks assigned to the reformers of the Common Agricultural Policy. Similarly, Zawojska (2006) negatively assessed the support distribution model under the direct payment scheme, stressing that it does not mitigate income disparities between holdings. Czyżewski and Stępień (2011) requested that more aid be provided to small holdings, and that a minimum level of direct payments be introduced for them, while applying a limit on subsidies for the largest holdings.

On the other hand, Kwasowski and Zaleski (2009) consider direct payments to be a significant factor hindering structural changes in Polish agriculture, which, in their opinion, is due to the fact that small holdings often prefer a small but stable income in the form of direct payments to the sale of land to dynamic holdings focused on commercial production. It should also be borne in mind that the introduction of solutions which reward a group of holdings which do not exceed a certain size, or the limit on the amount of aid, can induce farmers to adapt, motivated by the desire to maximise the benefits resulting from participation in the direct support system. In cases in which these measures do not bring environmental or social benefits, they are unproductive from the point of view of the general interest - they do not increase the overall level of prosperity, and they even mean a waste of resources and energy (Forstner et al., 2018; Sadłowski, 2020b).

In turn, studies on the redistributive payment, the results of which have been published so far, have involved simulations of the impact of its application and analyses of options (Matthews, 2013; Potori et al., 2013; Ivanov et al., 2015; Hansen \& Offermann, 2016; Chatellier, 2018), and, less frequently, the measurement of the actual impact as part of ex-post evaluations (Sadłowski, 2018, 2020a). Such studies can support the decision-making process regarding the development of the direct support system at the national level, hence their great application value. They provide knowledge that can facilitate evidence-based policy-making. 
The information gathered makes it possible to select the appropriate measures for the adopted agricultural policy objectives, which is the basis for its rationality (Sadłowski, 2020a). As Allanson (2006) observed, measuring the redistributive effects can be useful in devising the agricultural support policy, as it is a starting point for identifying ways of making this policy more effective as a redistributive tool, with this being just one of several criteria for assessing its effects.

\section{Materials and methods}

\subsection{Data sources}

The source materials used in the research part of this paper was data made available by the Ministries of Agriculture of the analysed countries - Bulgaria, Lithuania, and Poland. These data refer to 2018, and are summarised in Table 1.

Table 1. Source data used in the research, referring to 2018 (source: European Commission, 2019 data on area thresholds; the Ministry of Agriculture, Food, and Forests of the Republic of Bulgaria, the Ministry of Agriculture of the Republic of Lithuania, the Ministry of Agriculture and Rural Development of the Republic of Poland - other data concerning Bulgaria, Lithuania and Poland, respectively)

\begin{tabular}{|c|c|c|c|c|c|c|}
\hline \multicolumn{4}{|c|}{ Country } & Bulgaria & Lithuania & Poland \\
\hline \multicolumn{3}{|c|}{ Area threshold (ha) } & $x_{\min }$ & 0.5 & 1.0 & 1.0 \\
\hline \multicolumn{3}{|c|}{$\begin{array}{l}\text { The average size of a household in the group } \\
\text { of farmers benefiting from direct payments } \\
\text { (ha) }\end{array}$} & $\bar{x}$ & 65 & 23 & 11 \\
\hline \multirow{4}{*}{$\begin{array}{l}\text { Single area } \\
\text { payment }\end{array}$} & \multirow[b]{2}{*}{$\begin{array}{l}\text { Level of } \\
\text { financing }\end{array}$} & EUR thousand & $F_{S A P S}$ & 379,916 & 180,622 & $1,533,762$ \\
\hline & & $\begin{array}{l}\% \text { of the } \\
\text { national } \\
\text { ceiling }\end{array}$ & $F_{S A P S \%}$ & 47.80 & 38.00 & 44.70 \\
\hline & \multicolumn{2}{|c|}{ Rate (EUR/ha) } & $R_{\text {SAPS }}$ & 100.08 & 63.14 & 107.35 \\
\hline & \multicolumn{2}{|c|}{$\begin{array}{l}\text { Size of the agricultural } \\
\text { area covered by single area } \\
\text { payment (thousands ha) }\end{array}$} & $A_{S A P S}$ & $3,796.2$ & $2,860.7$ & $14,287.0$ \\
\hline \multirow{4}{*}{$\begin{array}{l}\text { Redistributive } \\
\text { payment }\end{array}$} & \multirow{2}{*}{$\begin{array}{l}\text { Level of } \\
\text { financing }\end{array}$} & EUR thousand & $F_{R E D}$ & 55,872 & 71,298 & 293,930 \\
\hline & & $\begin{array}{l}\% \text { of the } \\
\text { national } \\
\text { ceiling }\end{array}$ & $F_{R E D \%}$ & 7.03 & 15.00 & 8.57 \\
\hline & \multicolumn{2}{|c|}{ Rate (EUR/ha) } & $R_{R E D}$ & 70.33 & 57.88 & 41.62 \\
\hline & \multicolumn{2}{|c|}{$\begin{array}{l}\text { The hectare range on } \\
\text { a holding to which } \\
\text { redistributive payment is } \\
\text { granted }\end{array}$} & $\left(a_{R E D} ; b_{R E D}\right]$ & $(0 ; 30]$ & $(0 ; 30]$ & $(3 ; 30]$ \\
\hline
\end{tabular}




\subsection{The applied algorithm}

First, using simple statistical description methods, a general analysis was made of the structure of the distribution of national ceilings by the individual countries covered by the research.

Further analysis was conducted at the microeconomic level using mathematical methods. The description of the sequence of activities leading to the determination of area groups of holdings benefiting from/losing out on the application of the redistributive payment (in a given form and with a given level of funding) is as follows:

- Step 1. Calculation of the rate of the single area payment (EUR/ha) which would apply under the option without the redistributive payment, using the formula

$$
R_{\text {SAPS }}^{\prime}=\frac{F_{S A P S}+F_{R E D}}{A_{S A P S}} .
$$

- Step 2. Determination of the formula for the total amount of holding support in individual area groups for the option with the redistributive payment.

- Step 3. Determination of the formula for the total amount of holding support for the option without the redistributive payment.

- Step 4. Comparison of the appropriate formulae determined in Step 2 with the formula determined in Step 3.

- Step 5. Determination of the size of the holdings (ha) for which the application of the redistributive payment did not affect the amount of support received by solving the equations obtained in Step 3.

- Step 6. Determination of the area groups of holdings benefiting from/losing out on the application of the redistributive payment in a given form and at a given level of its financing, taking into account the limits of those area groups obtained in Step 5, and the so-called minimum requirements for receiving payments, under which the area thresholds indicated in the second row of Table 1 are established.

Calculations performed as part of the successive steps were compiled in Table 2. The respective symbols used in Table 2 have the following meaning:

$R_{\text {SAPS }}$ - single area payment rate (EUR/ha);

$R_{\text {SAPS }}^{\prime}$ - single area payment rate that would have applied had the redistributive payment not been applied (EUR/ha);

$R_{R E D}$ - redistributive payment rate (EUR/ha);

$F_{\text {SAPS }}$ - level of financing of the single area payment (EUR thousand);

$F_{R E D}$ - level of financing of the redistributive payment (EUR thousand);

$A_{\text {SAPS }}$ - agricultural area covered by the single area payment in the country (thousands ha);

$x$ - holding size (ha);

$P$ - the actual amount of support granted to the holding under the single area payment and the redistributive payment (EUR);

$P^{\prime}$ - the hypothetical amount of support granted to the holding under the single area payment in the option without the redistributive payment (EUR). 


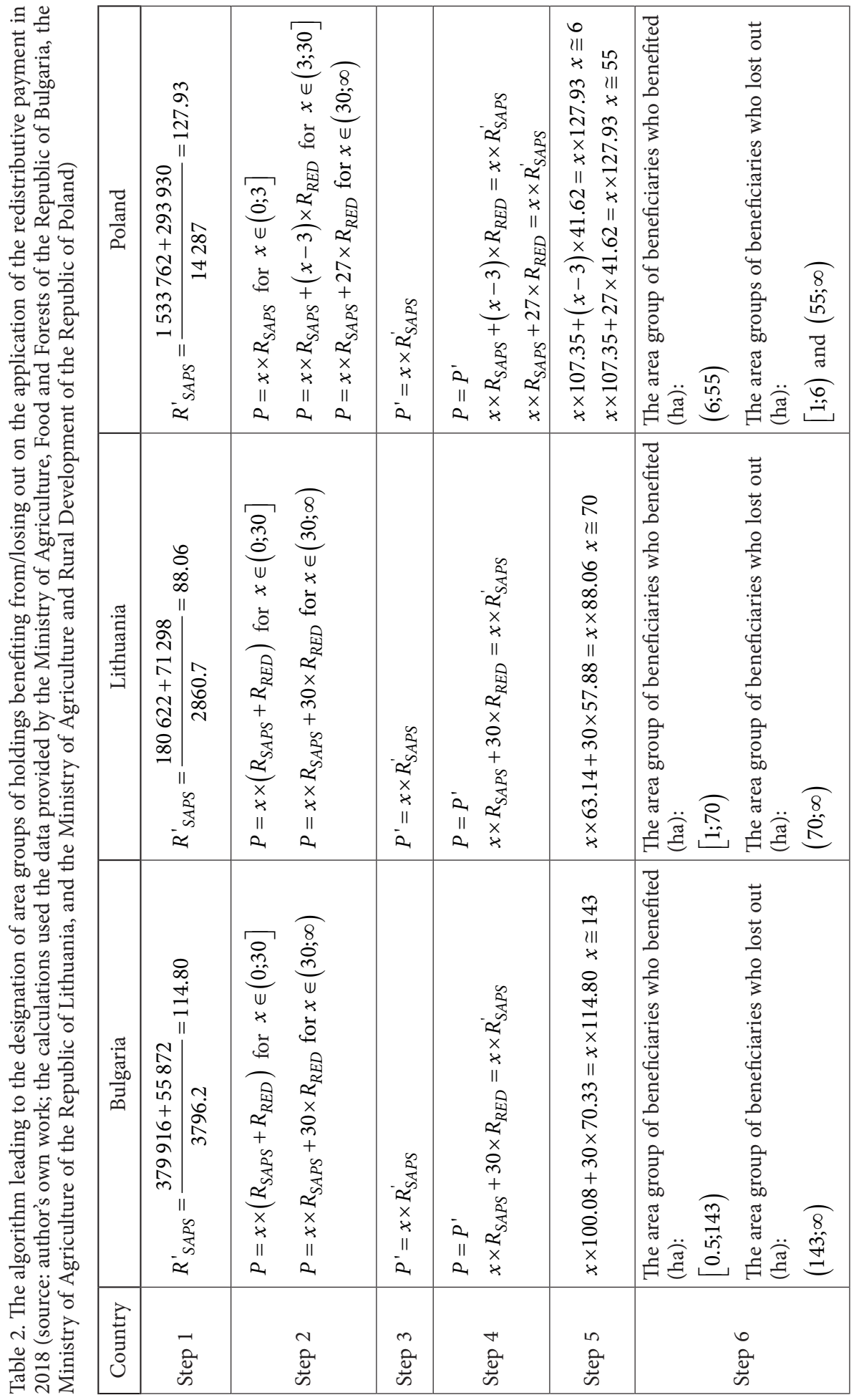


The applied method consists of juxtaposing an authentic example of the application of a redistributive payment (in a given form, and with a specific envelope for funding) with a hypothetical alternative situation in which the level of funding for the single-area payment would be increased by this very envelope.

This approach is consistent with the logic of structuring the national ceiling at the Member State level, as provided for in EU legislation. Since the allocation of a given part of the national ceiling to finance optional payments (which is the redistributive payment) is, at the same time, a decision to reduce the financing of the single area payment by exactly the same amount (in other words, the redistributive payment, like all other optional payments, is funded at the expense of the single area payment), it is reasonable to take as a benchmark this particular situation, in which the amount allocated to the redistributive payment would be apportioned to farmers under the single area payment.

In addition to identifying the area groups of holdings benefiting from/losing out on the application of the redistributive payment, function formulas were determined describing the following aspects in the individual countries under analysis:

1) the average amount of support (under the single area payment and the redistributive payment) per hectare of agricultural area in a holding,

2) the relative change in the average amount of support per hectare of agricultural area in a holding as a result of the introduction of the redistributive payment (compared to the situation in which the funds allocated to the redistributive payment would be disbursed under the single area payment),

depending on the size of the holding (Table 3). The progression of these functions is different for certain ranges of arguments (area groups).

Table 3. Determination of the average amount of holding support, depending on its size (source: author's own work)

\begin{tabular}{|l|l|l|l|}
\hline \multicolumn{2}{|c|}{ Country } & \multicolumn{1}{|c|}{ Bulgaria, Lithuania } & \multicolumn{1}{|c|}{ Poland } \\
\hline & $\begin{array}{l}\text { Option } \\
\text { without the } \\
\text { redistributive } \\
\text { payment }\end{array}$ & $\overline{P^{\prime}}=\frac{P^{\prime}}{x}=R_{S A P S}^{\prime}$ \\
\cline { 2 - 5 } & $\bar{P}=\frac{P}{x}=R_{\text {SAPS }}+R_{R E D}$ for & $\bar{P}=\frac{P}{x}=R_{S A P S}$ for $x \in(0 ; 3]$ \\
$\begin{array}{l}\text { Average } \\
\text { amount } \\
\text { of } \\
\text { support } \\
\text { per } \\
\text { hectare }\end{array}$ & $\begin{array}{l}\text { Option } \\
\text { with the } \\
\text { redistributive } \\
\text { payment }\end{array}$ & $\begin{array}{l}x \in(0 ; 30] \\
\bar{P}=\frac{P}{x}=R_{S A P S}+\frac{30 \times R_{R E D}}{x} \text { for } \\
x \in(30 ; \infty)\end{array}$ & $\begin{array}{l}\bar{P}=\frac{P}{x}=R_{S A P S}+\frac{(x-3) \times R_{R E D}}{x \in(3 ; 30]} \\
\bar{P}=\frac{P}{x}=R_{S A P S}+\frac{27 \times R_{R E D}}{x} \text { for } \\
x \in(30 ; \infty)\end{array}$ \\
\cline { 2 - 4 } & $\begin{array}{l}\text { Relative } \\
\text { change }\end{array}$ & $\Delta \bar{P}_{\%}=\frac{\bar{P}-\overline{P^{\prime}}}{\overline{P^{\prime}}}$
\end{tabular}


In Table 3, except for the previously used and explained symbols, the following average value expressions were used:

$\bar{P}$ - the actual average level of support to the holding under the single area payment and the redistributive payment (EUR/ha);

$\overline{P^{\prime}}$ - the hypothetical average level of support to the holding in the form of the single area payment in the option without the redistributive payment (EUR/ha).

\subsection{Presenting the results}

A bar chart with the structure of the distribution of national ceilings by individual countries was used to visualise the findings (Figure 1). As well as in formulas, the examined functional dependences are presented in diagrams (Figures 2 and 3).

\section{Results and discussion}

The financing of the redistributive payment may not exceed $30 \%$ of the national ceiling. None of the countries under analysis approached this limit. In 2018, Lithuania assigned the largest part of the national ceiling to financing the redistributive payment (15.00\%). In Poland and Bulgaria, the financing of the redistributive payment, measured as a percentage of the national ceiling, was similar, reaching $8.57 \%$ and $7.03 \%$, respectively.

On the other hand, the financing of the single area payment, measured as a percentage of the national ceiling, was the highest in Bulgaria at $47.80 \%$, in Poland $44.70 \%$ and in Lithuania $38.00 \%$.

As a result, taking both these payments together, a similar proportion of the national ceilings was allocated for their financing in the countries under analysis, i.e. $45.17 \%$ in Bulgaria, 46.73\% in Poland, and $47.00 \%$ in Lithuania. The structure of national ceilings in individual countries by directions of allocation is shown in Figure 1.

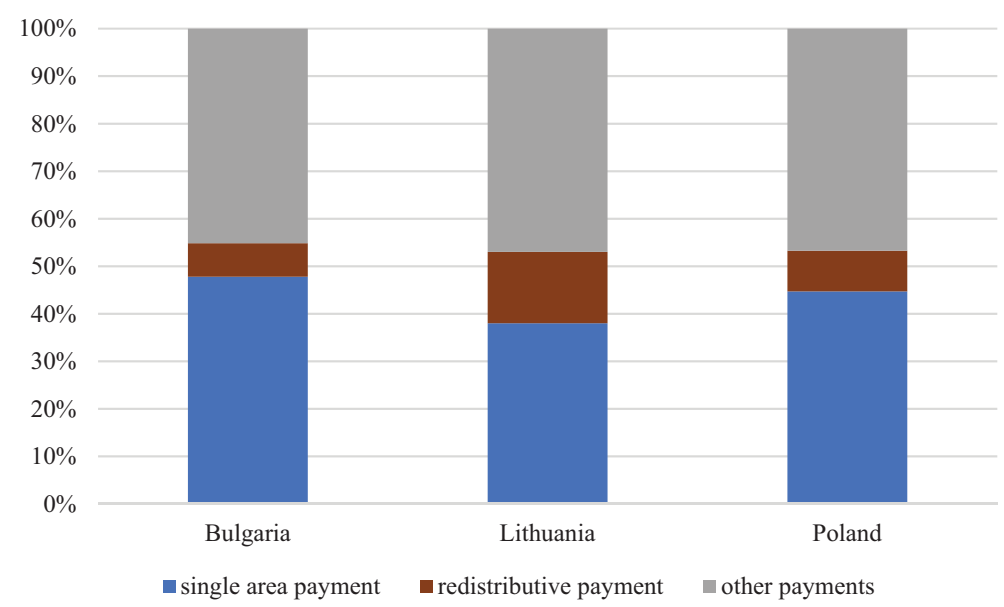

Figure 1. The structure of the national ceilings of the countries under analysis in 2018 (source: author's own work on the basis of the data provided by the Ministry of Agriculture, Food and Forests of the Republic of Bulgaria, the Ministry of Agriculture of the Republic of Lithuania and the Ministry of Agriculture and Rural Development of the Republic of Poland) 
On the other hand, Figure 2 shows the unit level of support in 2018 under the single area payment, and the redistributive payment, depending on the size of the holding (the continuous lines) in the countries compared. In addition, the dashed lines indicate the average level of support under the single area payment which would have existed if the redistributive payment had not been introduced, and thus the funds that were used to finance it would have been allocated in the form of the single area payment.

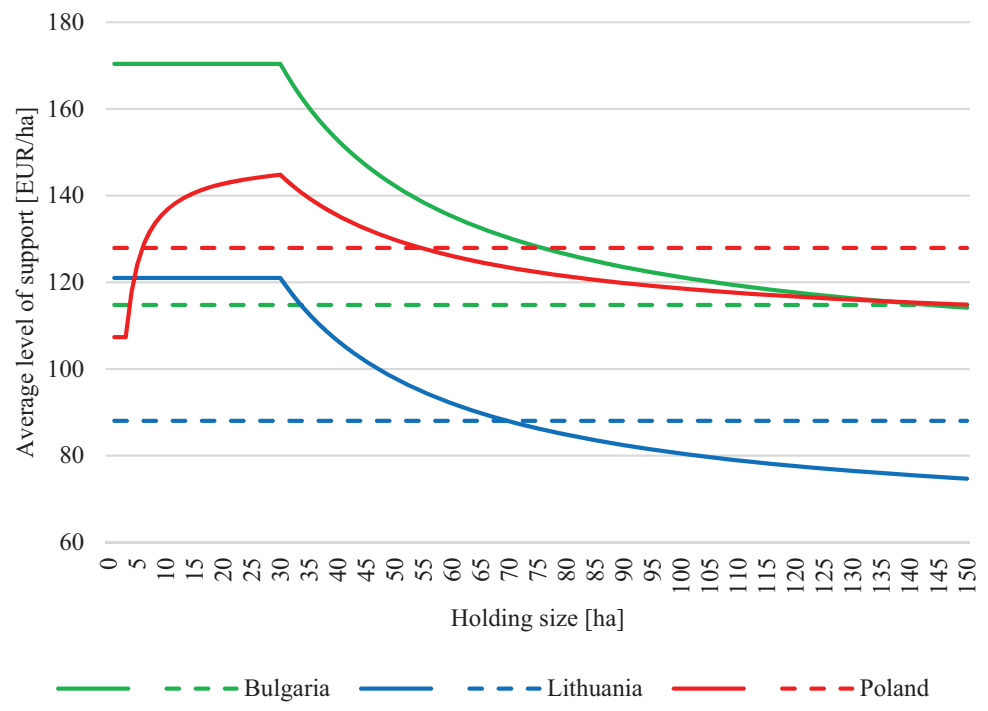

Figure 2. The impact of the redistributive payment on the average level of support in absolute terms, depending on the size of the holding (2018) (source: author's own work on the basis of data provided by the Ministry of Agriculture, Food and Forests of the Republic of Bulgaria, the Ministry of Agriculture of the Republic of Lithuania, and the Ministry of Agriculture and Rural Development of the Republic of Poland)

The point (or points) of intersection of the continuous lines of a given colour with the dashed lines of the same colour separates the area group of holdings which benefited from the application of the redistributive payment in 2018 in their country of agricultural activity (in a given form and with a given level of funding) from the area group (or groups) of holdings which lost out. As shown in Table 1, Bulgaria and Lithuania applied the redistributive payment to the "first" 30 hectares of agricultural area in a holding. In Poland, on the other hand, the redistributive payment was granted to those hectares of agricultural area included in a holding which fell within the range of $(3 ; 30]$. As a result, in Bulgaria and Lithuania, the unit level of support (under the single area payment and the redistributive payment) was the highest for holdings with an area not exceeding 30 ha. However, in Poland, the unit level of support under the two instruments was the highest for holdings with an area of 30 ha (the high point of the function line in Figure 2 in red).

In Bulgaria, for holdings with an area of 143.37 ha, the application of the redistributive payment was neutral, taking into account the amount of payment received. Holdings with an area below this threshold benefited from the application of the redistributive payment, while larger holdings lost out. In Lithuania, the size limit was approximately half, at 69.67 ha - 
smaller holdings gained, and larger ones lost out as a result of the introduction of the redistributive payment. In Poland, on the other hand, the privileged area group of holdings in connection with the application of the redistributive payment was made up of holdings with an area of more than 5.93 ha, but less than 54.60 ha. Holdings with an area equal to these limits would receive the same amount of support if the redistributive payment were not applied. Holdings with an area of less than 5.93 ha and holdings with an area of more than 54.60 ha lost out because of the application of the redistributive payment (in a given form), financing it at the expense of the single area payment. The described redistributive effects can be read from Figure 2.

Area groups of holdings benefiting from/losing out on the application of the redistributive payment can also be indicated using Figure 3, which shows the percentage increase or decrease in the average level of support per unit of area of agricultural land in a holding of a given size as a result of the application of the redistributive payment. In this case, the limits of the ranges are determined by the points of intersection of the function lines with the horizontal axis of the coordinate system.

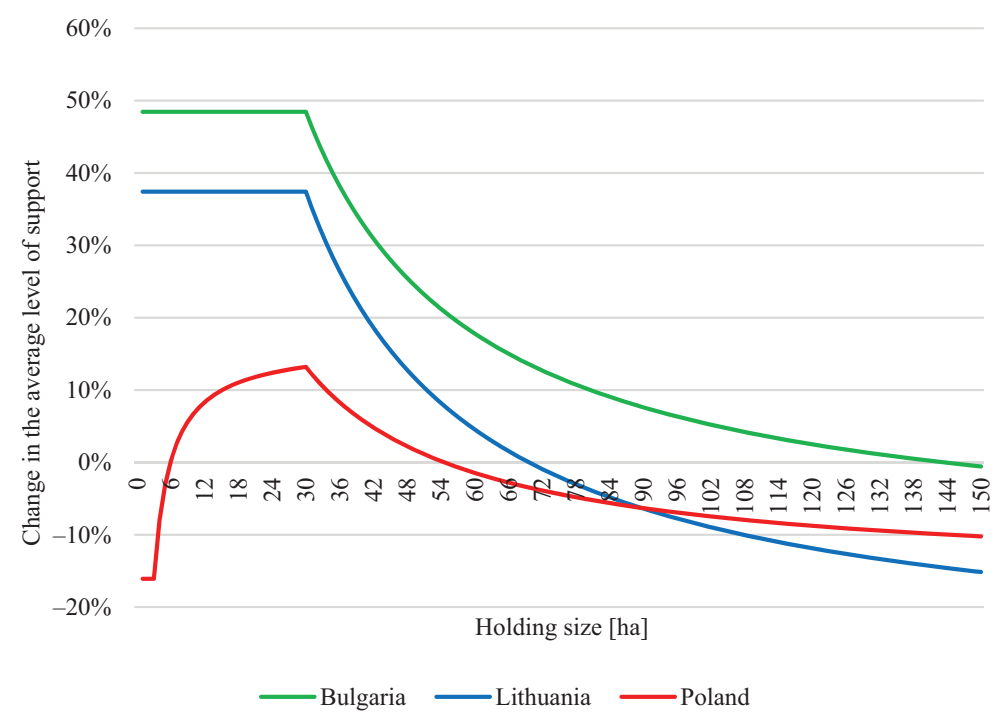

Figure 3. The impact of the redistributive payment on the average level of support in relative terms, depending on the size of the holding (2018) (source: author's own work on the basis of data provided by the Ministry of Agriculture, Food and Forests of the Republic of Bulgaria, the Ministry of Agriculture of the Republic of Lithuania, and the Ministry of Agriculture and Rural Development of the Republic of Poland)

The relative change in the average level of support per unit of area of land was obtained by dividing the difference between

- the amount granted to the holding under the single area payment and the redistributive payment (and not under all the instruments making up the direct support scheme for farmers), and

- the amount of the single area payment this holding would have received in the absence of the redistributive payment (then the level of financing of the single area 
payment would be higher by precisely the amount which the Member State concerned allocated to the redistributive payment),

by

- the amount of the single area payment this holding would have received in the absence of the redistributive payment.

As a result of the application of the redistributive payment, the relatively largest increase in the average level of support per unit of area of agricultural land (by more than 48\%) was recorded by holdings in Bulgaria. These were holdings with an area of up to 30 ha. Despite this redistributive effect, the uneven distribution of aid in Bulgaria continues to increase, which is explained by the structural changes taking place in the country, involving the disappearance of small holdings, the persistence of a relatively small group of medium-sized holdings which, due to their small number, do not play a significant role in absorbing financial support, and the continuous development of large holdings, which are thus gathering more and more financial support (Beluhova-Uzunova et al., 2020). In Lithuania, an increase in the average level of support per unit of area of agricultural land was much smaller, amounting to approx. $37 \%$. In Poland, on the other hand, the holdings with an area of 30 ha benefited most, with an increase of only slightly over $13 \%$. In the case of holdings with an area of less than 3 ha, the decrease in this amount exceeded $16 \%$.

The strongest redistributive effect in relative terms, achieved in Bulgaria with the lowest level of financing of the redistributive payment expressed as a percentage of the national ceiling allocated to this payment, can be explained by the weakest fragmentation of holdings in that country. The average holding size in the group of farmers benefiting from direct payments is approx. 65 ha in Bulgaria. By allocating more than twice as much of the national ceiling as Bulgaria to the redistributive payment, and by targeting support in the same way (i.e. to the "first" 30 hectares of agricultural area in a holding), Lithuania achieved a much weaker redistributive effect. The average increase in the level of support per unit of area of agricultural land in the group of holdings with an area of no more than 30 ha was about 11 percentage points lower in Lithuania than in Bulgaria, with the average size of the holding benefiting from direct payments' being about 23 ha in Lithuania. In Poland, the impact of the redistributive payment was the weakest. This is a consequence of the relatively low level of financing of the redistributive payment under the conditions of the very fragmented area structure of holdings (the average area of the holdings benefiting from direct payments is about $11 \mathrm{ha}$ ). As a result, the aid channelled through the redistributive payment was spread over a large area of agricultural land, relatively weakly "raising" the average level of support in the group of holdings benefiting from this instrument. This is despite the fact that in Poland - as the only Member State of the European Union among the countries which have implemented the redistributive payment - this payment is not granted to the "first" hectares, but to the surplus hectares over 3, but no more than 27. This solution means that the owners of holdings with an area not exceeding 3 ha are excluded from the group of beneficiaries of the redistributive payment. 


\section{Conclusions}

Bulgaria, Lithuania and Poland make relatively little use in absolute terms of the potential of the redistributive payment to bridge the gap in the level of holding support, allocating a much smaller part of the national ceiling to its financing than is allowed by EU legislation. This means that reducing the degree of the concentration of aid in these countries does not require a change to the EU legal framework. One of the options for ensuring a more even distribution of support between beneficiaries would be to increase the funding level of redistributive payments to $30 \%$ of the national ceiling.

The upper limit of the size range of holdings benefiting from the redistributive payment is shifted to the right in relation to the upper limit of the hectare range of the holdings covered by the redistributive payment. In Bulgaria and Lithuania, the redistributive payment is granted up to the "first" 30 ha of agricultural area in a holding, while the area group of holdings benefiting from this instrument is made up of holdings with less than 143 and 70 ha, respectively. Also, in Poland, the redistributive payment may cover a maximum of "thirty" hectares of agricultural area included in a holding, with the "first three" hectares of agricultural area of the holding's being excluded from support under this instrument. As a result, the application of the redistributive payment in this form is unfavourable, not only for a group of holdings exceeding a certain size (specifically, for holdings with an area of more than $55 \mathrm{ha}$ ), but also for the smallest beneficiaries (strictly speaking, for owners of holdings with an area of less than $6 \mathrm{ha}$ ).

Thus, in all the countries under analysis, the upper limit of the area range of holdings benefiting from the redistributive payment is significantly higher than the upper limit of the number of hectares of agricultural land in a holding which might be eligible for the redistributive payment.

Although in Bulgaria the smallest proportion of the national ceiling has been allocated for financing the redistributive payment among the countries compared, and the range of hectares covered by this payment is larger than in Poland and the same as in Lithuania, the redistributive payment rate in Bulgaria was the highest. The redistributive payment has led to the largest relative increase in the average level of support per hectare of agricultural area in Bulgaria for the smallest holdings, as a result of the fact that they represent a relatively small group in that country, and therefore the relatively small envelope distributed as part of the redistributive payment has allowed the average level of support per hectare in this group of holdings to be "raised" relatively strongly.

Although the research of which the results are presented in this paper has made it possible to identify groups of holdings benefitting from redistributive payments, and to determine the impact of redistributive payments on the average level of support per hectare of agricultural land in holdings according to their size (area), it has proven insufficient for answering the question of whether the relative increase in the income of holdings advantaged due to the application of redistributive payments to other beneficiaries is a sufficiently strong stimulus to change the area structure of holdings in a given country. Therefore, further research in this area could focus on determining whether redistributive payments have influenced trends towards structural changes in the agriculture of the respective countries using this instrument, including the dynamics of land concentration processes. 


\section{Acknowledgements}

The author would like to thank the Ministry of Agriculture, Food, and Forests of the Republic of Bulgaria, the Ministry of Agriculture of the Republic of Lithuania and the Ministry of Agriculture and Rural Development of the Republic of Poland for providing the data.

\section{Disclosure statement}

The author declares no conflict of interest.

\section{References}

Alfaro-Navarro, J. L., Mondejar-Jimenez, J., Vargas-Vargas, M., Gazquez-Abad, J. C., \& Jimenez-Guerrero, J. F. (2011). The effects of the distribution of agricultural direct payments. Review of Business Information Systems, 15(5), 25-30. https://doi.org/10.19030/rbis.v15i5.6015

Allanson, P. (2006). On the characterisation and measurement of the redistributive effects of agricultural policy (Dundee Discussion Papers in Economics, 188). University of Dundee.

Baisakova, N., \& Herzfeld, T. (2014). Aspekte der Agrarpolitik 2013. German Journal of Agricultural Economics, 63(Suppl.), 1-11.

Beluhova-Uzunova, R., Atanasov, D., \& Hristov, K. (2017). Analisys of direct payments distribution in Bulgarian agriculture. Trakia Journal of Sciences, 15(Suppl. 1), 282-287. https://doi.org/10.15547/tjs.2017.s.01.051

Beluhova-Uzunova, R., Atanasov, D., \& Shishkova, M. (2019). Direct payments in Bulgaria - Trends and perspectives. Bulgarian Journal of Agricultural Economics and Management, 64(3), 42-50.

Beluhova-Uzunova, R., Atanasov, D., \& Shishkova, M. (2020). Distribution of direct payments in Bulgaria - policy lessons and prospects beyond 2020. Scientific Papers Series Management, Economic Engineering in Agriculture and Rural Development, 20(2), 53-59.

Chatellier, V. (2018, Jun 20-21). Le paiement redistributif et le plafonnement des aides directes: deux outils de la PAC favorables aux petites exploitations agricoles françaises? Colloque de la SFER "Politiques agricoles et alimentaires: trajectoires et réformes". Montpellier, France.

Ciliberti, S., \& Frascarelli, A. (2015, October 7-8). The role of CAP in enhancing farm incomes: The redistributive effect of direct payments in Italy. Paper prepared for presentation at the $147^{\text {th }}$ EAAE Seminar "CAP Impact on Economic Growth and Sustainability of Agriculture and Rural Areas". Sofia, Bulgaria.

Czyżewski, A., \& Stępień, S. (2011). Common agricultural policy of the EU after 2013 and the interests of the Polish agriculture. Ekonomista, 1, 9-36.

Deppermann, A., Offermann, F., \& Grethe, H. (2016). Redistributive effects of CAP liberalisation: From the sectoral level to the single farm. Journal of Policy Modeling, 38(1), 26-43. https://doi.org/10.1016/j.jpolmod.2015.11.002

European Commission. (2016). Redistributive payment. https://ec.europa.eu/info/sites/info/files/foodfarming-fisheries/key_policies/documents/ds-dp-redistributive-payment_en.pdf

European Commission. (2018). Direct payments. https://ec.europa.eu/info/sites/info/files/food-farming-fisheries/farming/documents/direct-payments_en.pdf

European Commission. (2019). Direct payments. Eligibility for direct payments of the Common Agricultural Policy. https://ec.europa.eu/info/sites/info/files/food-farming-fisheries/key_policies/documents/direct-payments-eligibility-conditions_en.pdf 
European Parliament and Council of the European Union. (2013). Regulation (EU) No 1307/2013 of the European Parliament and of the Council of 17 December 2013 establishing rules for direct payments to farmers under support schemes within the framework of the common agricultural policy and repealing Council Regulation (EC) No 637/2008 and Council Regulation (EC) No 73/2009 (OJ L 347, 20.12.2013, p. 608, and its subsequent amendments).

Eurostat. (2021). Farm indicators by agricultural area, type of farm, standard output, legal form and NUTS 2 regions. Retrieved April 24, 2021, from https://ec.europa.eu/eurostat/databrowser/view/ ef_m_farmleg/default/table?lang=en

Forstner, B., Duden, Ch., Ellßel, R., Gocht, A., Hansen, H., Neuenfeldt, S., Offermann, F., \& de Witte, T. (2018). Wirkungen von Direktzahlungen in der Landwirtschaft - ausgewählte Aspekte mit Bezug zum Strukturwandel (Thünen Working Paper, 96). https://doi.org/10.3220/WP1524561399000

Graca-Gelert, P. (2014). The impact of European funds on income inequality in Poland - the example of direct payments and structural pensions. Social Inequalities and Economic Growth, 38(2), 180-190.

Grochowska, R., Pawłowska, A., \& Skarżyńska, A. (2021). Searching for more balanced distribution of direct payments among agricultural farms in the CAP post-2020. Agricultural Economics, 67(5), 181-188. https://doi.org/10.17221/417/2020-AGRICECON

Hansen, H., \& Offermann, F. (2016). Direktzahlungen in Deutschland - Einkommens- und Verteilungswirkungen der EU-Agrarreform 2013. German Journal of Agricultural Economics, 65(2), 77-93.

Ivanov, B., Malamova, N., \& Sokolova, E. (2015, October 7-8). The new direct payments paradigm in the CAP 2014-2020: economic effects of "green" and redistributive payments on Bulgarian agriculture. Paper prepared for presentation at the $147^{\text {th }}$ EAAE Seminar "CAP Impact on Economic Growth and Sustainability of Agriculture and Rural Areas". Sofia, Bulgaria.

Jankowska, A. (2015). Direct paymants concentration in the countries of central and eastern Europe in the year 2012. Annals of the Polish Association of Agricultural and Agribusiness Economists, 17(4), 98-103.

Keeney, M. (2000). The distributional impact of direct payments on Irish farm incomes. Journal of Agricultural Economics, 51(2), 252-265. https://doi.org/10.1111/j.1477-9552.2000.tb01227.x

Kwasowski, M., \& Zaleski, S. (2009). Die Landwirtschaft in Polen fünf Jahre nach dem Beitritt zur Europäischen Union. Polen-Analysen, 51, 2-7. https://doi.org/10.31205/PA.051.01

Matthews, A. (2013). Implications of the new redistributive payment. http://capreform.eu/implications-of-the-new-redistributive-payment/

Potori, N., Kovács, M., \& Vásáry, V. (2013). The common agricultural policy 2014-2020: an impact assessment of the new system of direct payments in Hungary. Studies in Agricultural Economics, 115(3), 118-123.

Sadłowski, A. (2017). Distribution of funds under the direct support scheme between beneficiaries analysis of inequality and redistributive instruments introduced in 2015. Problems of Agricultural Economics, 353(4), 169-187. https://doi.org/10.30858/zer/84962

Sadłowski, A. (2018). Optional payments of the first pillar under CAP vs the average amount of support per farm. Economic and Regional Studies, 11(3), 148-161. https://doi.org/10.2478/ers-2018-0031

Sadłowski, A. (2020a). Einfluss der fakultativen Direktzahlungen auf die durchschnittliche Höhe der Stützung für einen landwirtschaftlichen Betrieb in Polen in regionaler Perspektive. Berichte über Landwirtschaft, 98(3), 1-24.

Sadłowski, A. (2020b). The planned reform of the Common Agricultural Policy with particular reference to the direct support system. Agricultural Economics, 66(8), 381-390. https://doi.org/10.17221/397/2019-AGRICECON

Sahrbacher, Ch. (2011, October 4-6). Auswirkungen einer Obergrenze für Direktzahlungen an Großlandwirte. 21. Jahrestagung der Österreichischen Gesellschaft für Agrarökonomie. Bolzano, Italy. 
Severini, S., \& Tantari, A. (2013a). The effect of the EU farm payments policy and its recent reform on farm income inequality. Journal of Policy Modeling, 35(2), 212-227. https://doi.org/10.1016/j.jpolmod.2012.12.002

Severini, S., \& Tantari, A. (2013b). The impact of agricultural policy on farm income concentration: The case of regional implementation of the CAP direct payments in Italy. Agricultural Economics, 44(3), 275-286. https://doi.org/10.1111/agec.12010

Severini, S., \& Tantari, A. (2015). Which factors affect the distribution of direct payments among farmers in the EU Member States? Empirica, 42, 25-48. https://doi.org/10.1007/s10663-013-9243-X

Sinabell, F., Schmid, E., \& Hofreither, M. F. (2019). The distribution of direct payments of the common agricultural policy. Jahrbuch der Österreichischen Gesellschaft für Agrarökonomie, 18(1), 111-119.

Šlajs, J., \& Doucha, T. (2014). Situation in the Czech agriculture after 9 years of EU accession - a research position to strategic challenges for a future policy after 2013. Problems of Agricultural Economics, 338(1), 116-127.

Von Witzke, H., \& Noleppa, S. (2007). Agricultural and trade policy reform and inequality: The distributive effects of direct payments to German farmers under the EU's new common agricultural policy (Working Paper No. 79/2007). Albrecht Daniel Thaer-Institut für Agrar- und Gartenbauwissenschaften, Humboldt-Universität zu Berlin. http://doi.org/10.22004/ag.econ.10289

Wilkin, J. (2009). The political economics of the common agricultural policy reform. The Polish Journal of Economics, 229(1-2), 1-25. https://doi.org/10.33119/GN/101222

Zawojska, A. (2006). Socio-economic aspects of EU direct payments. Annals of the Polish Association of Agricultural and Agribusiness Economists, 8(4), 400-404. 